\title{
Biology and Captive Breeding of the Amazonian Milk Frog, Trachycephalus resinifictrix (Goeldi 1907)
}

\author{
Fabien Mignet \\ 31 rue Tony Révillon, 01750 Saint-Laurent-sur-Saône, France (fabien.mignet@gmail.com) \\ Photographs by the author except where noted.
}

\begin{abstract}
Although the Amazonian Milk Frog (Trachycephalus resinifictrix) is commonly bred in captivity in zoological institutions worldwide, very little information regarding these undertakings has been published. Here, I report my experience with the successful breeding of T. resinifictrix at the Touroparc Zoo. I highlight some fundamental biological traits in order to fulfill the requirements for captive breeding and to ensure the general welfare of these frogs. The aim is to provide guidelines that may be used by zoos, aquariums, and other facilities as well as private contributions to conservation breeding programs for endangered anurans with requirements similar to those of T. resinifictrix. In general, this species is easy to keep in captivity. Larvae are easy to produce and raise with very low mortality rates. They usually metamorphose at six to ten weeks. However, newly metamorphosed frogs are fragile and require more attention. Several pathogens are known to affect the health of amphibians, and stress can play an important role in immune function.
\end{abstract}

Keywords: Anura, Hylidae, Trachycephalus resinifictrix, captive husbandry, conservation

$\mathrm{T}$ The Amazonian Milk Frog (occasionally called the Mission Golden-eyed Tree Frog; Fig. 1) was originally described as Hyla resinifictrix by Goeldi (1907). After several taxonomic changes, the species is now placed in the genus Trachycephalus (Faivovich et al. 2005). The genus Trachycephalus includes the following 13 species besides $T$. resinifictrix: T. typhonius Linnaeus 1758 (previously recognized as T. venulosus; $\mathrm{Da}$ Luz Soares et al. 2012), T. nigromaculatus Tschudi 1838; T. mesophaeus Hensel 1867; T. coriaceus Peters 1867; T. jordani Stejneger and Test 1891; T. imitatrix Miranda-Ribeiro 1926; T. atlas Bokermann 1966; T. hadroceps Duellman and Hoogmoed 1992; T. lepidus Pombal, Haddad, and Cruz 2003; T. dibernardoi Kwet and Solé 2008; T. mambaiensis Cintra, Silva, Silva Jr., Garcia, and Zaher 2009, T. helioi Nunes, Suárez, Gordo, and Pombal 2013, T. cunauaru Gordo, Toledo, Suárez, Kawashita-Ribeiro, Ávila, Morais, and Nunes 2013.

The Amazonian Milk Frog is known to occur in eastern Suriname, central Guyana, Brazil, Ecuador, Columbia, Bolivia, Peru, French Guiana, and Venezuela. This species is found at elevations between 0 and $450 \mathrm{~m}$ (La Marca et al. 2010). Diagnostic characters of the species are the presence of a short, blunt snout, no folds except a low supratympanic crest that does not cover the upper edge of the tympanum, a large dorsal patch, a granular venter, dorsum and sides covered with small pustules, and large size. Females can reach $86-100 \mathrm{~mm}$ in snout-vent length (SVL) and generally are larger than males (65-77 $\mathrm{mm} \mathrm{SVL).}$

Trachycephalus resinifictrix is a nocturnally active arboreal species that inhabits the canopy of tropical primary rainforest, where it breeds in phytotelmata (exclusively tree holes: Schiesari et al. 1996; Lescure and Marty 2000; Schiesari et al. 2003; Verschooren et al. 2011). Tree holes used by Amazonian Milk Frogs are circular to elliptical, with areas of $62.8-451.4 \mathrm{~cm}^{2}$, depths between 15 and $190 \mathrm{~cm}$, and water volumes of 2.8-90 1 (Schiesari et al. 2003). According to the same authors, tree holes are located between 2 and 32 $\mathrm{m}$ above ground level, exhibit $\mathrm{pH}$ values of approximately 6.0-7.0, and dissolved oxygen contents of $0.2-3.9 \mathrm{mg} / \mathrm{l}$. Males call from tree holes to attract females, usually between August/September and April/May (i.e., during the rainy season). However, the mating period can differ across localities (Schiesari et al. 2003).

The IUCN lists $T$. resinifictrix as a taxon of Least Concern because of its wide distribution and presumed large population size; although this species is not currently threatened overall, local populations are impacted by habitat 


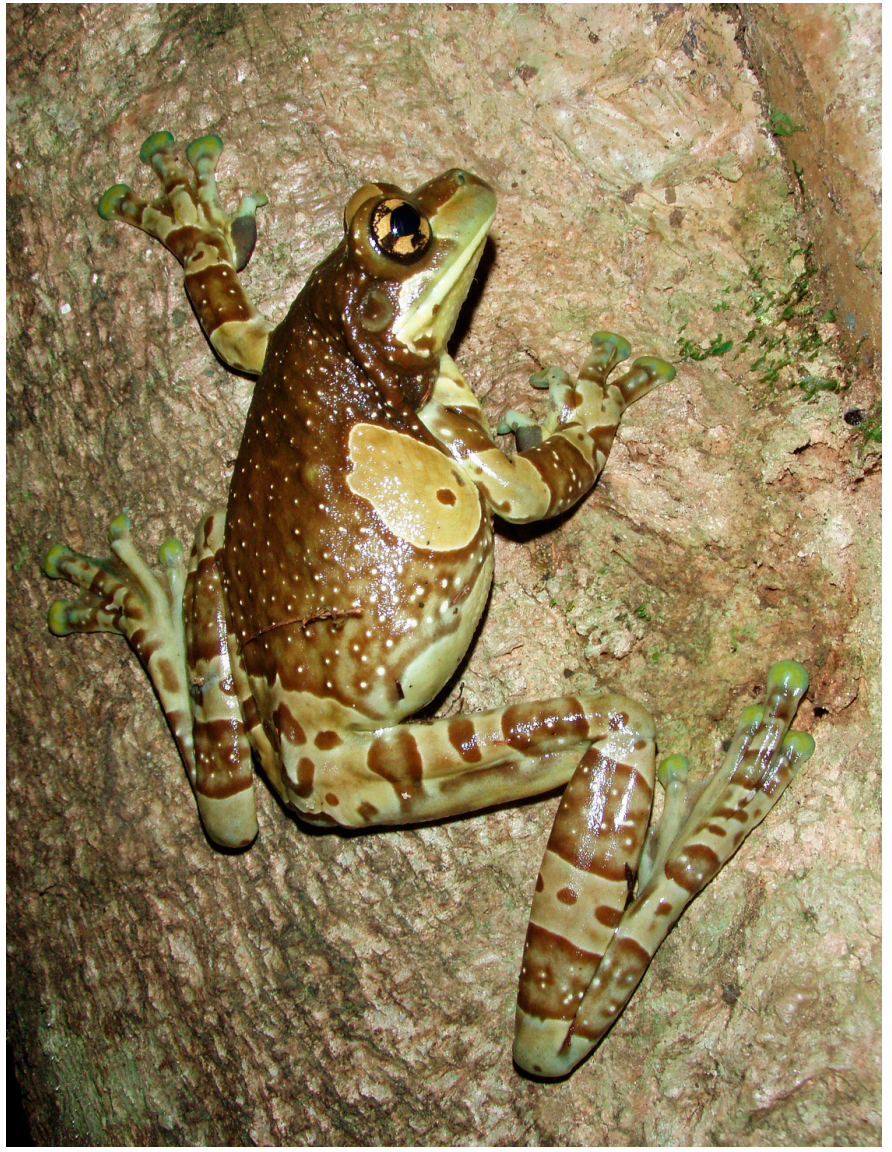

Fig. 1. Amazonian Milk Frogs (Trachycephalus resinifictrix) are native to northern South America. Photograph Philippe Gaucher (Technical Director of Field Stations, CNRS Guyane/USR 3456).

destruction and disturbance as a result of logging and expanding human settlements and agriculture (La Marca et al. 2010). Amphibians are declining globally and approximately one-third of all species are threatened with extinction (Lötters et al. 2009). The infectious fungal disease chytridiomycosis is considered one of the major drivers of global amphibian population decline and extinction (Daszak et al. 1999; Lips et al. 2006; Rachowicz et al. 2006). Because of the global amphibian crisis, captive breeding programs have become major tools in efforts to conserve many amphibian species (Griffiths and Pavajeau 2008; Browne et al. 2011; Zippel et al. 2011; Croteau and Mott 2013). Indeed, amphibians are the most threatened taxonomic group among vertebrates and probably best suited to captive breeding (Marris 2008). The most prominent example is the increase of amphibian collections in zoos as a response to the many factors threatening these animals, prominent among them the effects of chytridiomycosis (Rosa et al. 2015).

The Amazonian Milk Frog has been kept in captivity for nearly two decades, but very few data on rearing conditions have been published in scientific journals. Herewith I present my experience with the successful maintenance and breeding of T. resinifictrix at the Touroparc Zoo (Burgundy, France).

\section{Materials and Methods}

Captive management of adults. - Both adults are from the menagerie of the Jardin des Plantes in Paris (France). These two Amazonian Milk Frogs were permanently maintained at the breeding unit (without public access) at Touroparc Zoo, housed in a glass terrarium $(\mathrm{L} 60 \times \mathrm{W} 45 \times \mathrm{H} 90 \mathrm{~cm})$ that was divided into aquatic and terrestrial sections. In the wild, $T$. resinifictrix is known to breed in tree holes above ground level, whereas in captivity it can breed in a basin at ground level. However, artificial tree holes that retain water spray can be created in the upper part of the terrarium in order to mimic natural conditions. In our system, the aquatic portion is about $15 \mathrm{~cm}$ in depth. The physico-chemical parameters of the osmosed water used are: $\mathrm{pH}=6.5, \mathrm{GH}$ (total hardness of water) $<1, \mathrm{KH}$ (carbonate hardness of water) $<1$. The $\mathrm{pH}$ value is similar to that observed in their natural environment (Schiesari et al. 2003).

The terrestrial portion is made from elastopur (a two-component adhesive) with sphagnum peat, lianas, roots, and stones. The background and sides were covered with coconut fiber modules to provide a natural looking environment. A variety of natural plants (e.g., mosses, large bromeliads) completed the arrangement (Fig. 2). The enclosure was housed in a room heated to $24-29^{\circ} \mathrm{C}$ (night/ day) during the summer and $22-24^{\circ} \mathrm{C}$ (night/day) during the winter. A Reptisun 5.0 UV-B lamp was used for lighting (only the lighting needed for animals is mentioned here), and set on a timer to maintain a 12-hour photoperiod to maximize reproductive success and fecundity (per recommendations in Schultz and Douglas 2003). The humidity was kept at $50-90 \%$ by using an automatic spray system, and air circulation is ensured by two small fans placed in the top of the enclosure.

Husbandry of larvae.-Eggs were left in the terrarium with the adults until hatching. The rearing tank for larvae at early stages consisted of a glass aquarium containing 15-20 l of osmosed water (see physico-chemical parameters described above). In nature, bottoms of tree holes usually are covered by one or more layers of dead leaves and decaying organic matter (Schiesari et al. 2003). In order to recreate similar conditions and soften the water, dead oak leaves were added on the bottom of the aquarium. Another alternative would be to use tropical almond (Terminalia catappa) leaves sold in specialty shops. Just like oak leaves, the secondary metabolites of the tropical almond leaves, such as, tannins, alkaloids, flavonoids, and saponins, have antifungal and antibacterial properties (Mandloi et al. 2013; Neelavathi et al. 2013), which protect tadpoles from infections. An air sponge filter was used for filtration (Fig. 3A). This system is inexpensive, and it ensures effective water treatment without affecting the integrity of the tadpoles. The water was not heated and temperature fluctuated between 23 and $25^{\circ} \mathrm{C}$. Partial (approximately 30\%) water changes occurred three times per week. However, the period between water changes depended among other factors on feed rates, type of feed, and water temperature (Culley 1992). Tadpole density must also be taken into account when determining the frequency of water changes. In nature, larval density can be high, up to 16 tadpoles/liter (Schiesari et al. 2003). This maximum breeding den- 

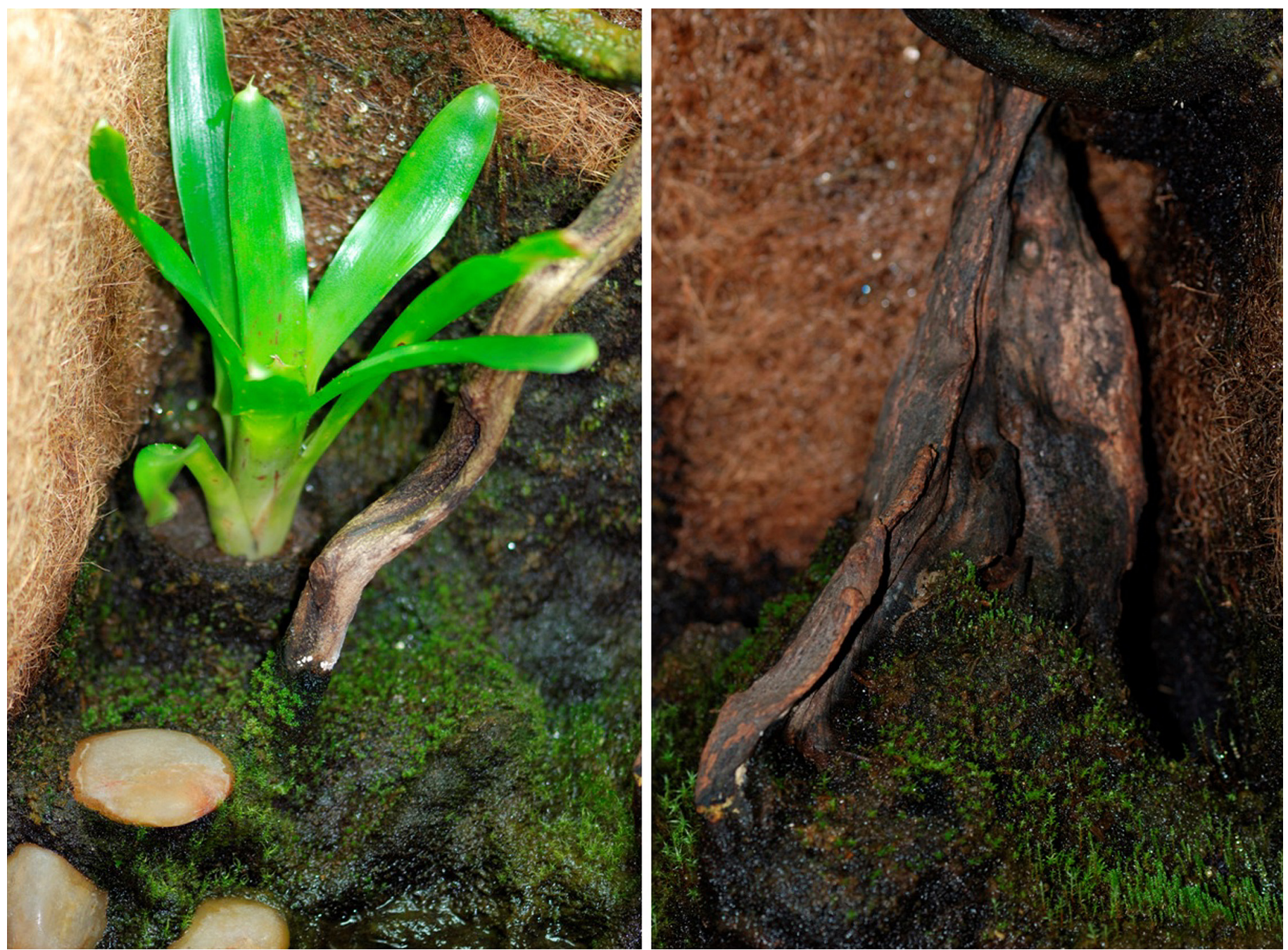

Fig. 2. Enclosure for the adult Amazonian Milk Frogs (Trachycephalus resinifictrix). The moss develops progressively throughout the landscape.

sity was widely respected and equated to about $240-320$ tadpoles (i.e., $16 \times 15=240,16 \times 20=320$ ). Nonetheless, raising tadpoles at lower densities by using additional aquaria minimizes the risk of food competition.

The most developed tadpoles were successively transferred into another aquarium, containing approximately 20-25 1 of osmosed water (unheated) with dead oak leaves and a floating dock (Fig. 3B). Partial water changes were also made three times a week. In order to save time and space, both aquaria can be combined in a single tank. However, I strongly recommend separating the two aquaria to facilitate the monitoring of growth and development of the tadpoles.

Housing for metamorphs and juveniles.-Metamorphs and juveniles were kept in groups of $15-20$ in glass terraria $\left(\right.$ Exo-Terra $\left.^{\circledR}\right)$ measuring L30 $\times \mathrm{W} 30 \times \mathrm{H} 45 \mathrm{~cm}$ that included a small water basin, cork bark for hiding places, bamboo, and artificial plants (Fig. 3C). Newly metamorphosed frogs are poor swimmers and can easily drown. Consequently, water depth in the basin was about $5 \mathrm{~mm}$, allowing metamorphs to keep their heads above water and prevent drowning. For hygienic reasons, the substrate was absorbent paper towel that was kept permanently damp. Wet sphagnum moss can also be used as a substrate. Metamorphs were maintained at the same temperature as adults $\left(24-29^{\circ} \mathrm{C}\right)$, and were misted with roomtemperature osmosed water twice daily (morning and evening).

Well documented negative effects of exposure to ambient levels of UV-B radiation on amphibians were reviewed in Blaustein et al. (2003) and Croteau et al. (2008). UV-B exposure in amphibians can reduce hatching success (Häkkinen et al. 2001), induce developmental and physiological deformities (Hays et al. 1996; Fite et al. 1998; Ankley et al. 2002), alter growth rates (Pahkala et al. 2003), cause severe skin damage and/or darkening (Nagl and Hofer 1997; Langhelle et al. 1999), decrease survival (Blaustein et al. 2005), and alter behavior (Blaustein et al. 2000; Kats et al. 2000). However, these effects are species-specific, vary with life-history stage, and depend on context. According to Hays et al. (1996), low-level exposure to simulated ambient UV-B radiation in the laboratory causes a number of developmental and physiological deformities in frogs. These include edema, skeletal anomalies, and eye damage (Blaustein et al. 2003). Therefore, to prevent similar problems and improve the overall growth of juveniles, illumination was provided by a 
UV-B fluorescent lamp (Zoo Med Reptisun ${ }^{\circledR}$ 5.0 Tropical UV-B. The choice of power (i.e., \% of UVB output) for the UV-B lamp is based on the model used in a study conducted by Verschooren et al. (2011), but also is influenced by the ecology of the species. One recent investigation (Verschooren et al. 2011) has shown that for $T$. resinifictrix, daily exposure to UV-B significantly improves growth and skeletal development. Due to the potentially beneficial effects of UV-B on amphibian health, I highly recommend using UV-B lighting for captive amphibians that may need UV-B in their natural environments. In general, many amphibians prefer rather cool conditions with subdued light. Accordingly, low-power UV-B fluorescent lamps should be used rather than high-temperature UV-B lights. As a general rule, adequate power UV-B is usually between $2 \%$ and $5 \%$ for amphibians that require UV-B in captivity.

As metamorphs grew, they were sorted by size into additional enclosures. Reducing density avoids the risk of food competition. Most juveniles are reared to $2-3 \mathrm{~cm}$ and then transferred to other interested zoological institutions.

Diet, nutrition, and associated diseases. - Successfully maintaining amphibians in captivity can be difficult due to their fastidious and changing nutritional requirements over different life stages (Densmore and Green 2007). However, diets of captive animals are often restricted by the commercial availability of food. Consequently, diets need to be adapted to avoid any risk of malnutrition.

Adults were fed two or three times per week during active periods, mostly on various insects (Acheta domesticus and Locusta migratoria). In the wild, tadpoles feed on algae, vegetable detritus, and sometimes conspecific eggs (opportunistic oophagy). At Touroparc Zoo, tadpoles were fed on fine ornamental fish food (TetraMin ${ }_{\text {Baby }}^{\circledR}$ ) 2-3 times per day in adequate quantity. During the latter phase of metamorphosis, tadpoles ceased to feed until the tail was completely resorbed. Froglets were fed daily until about 5-6 weeks of age with live pin-head crickets ( $A$. domesticus) and occasionally fruit flies (Drosophila hydei). After roughly 7-8 weeks, the interval was progressively increased to once every 2-3 days. Insects (except for fruit flies) were fed a complete feeder diet (Repashy Superfoods ${ }^{\circledR}$ Bug Burger) and dusted with a mineral and vitamin supplement (Nutrobal ${ }^{\circledR}$ or equivalent).

In captivity, nutritional diseases are relatively common in insectivorous animals. Among the specific dietary problems that
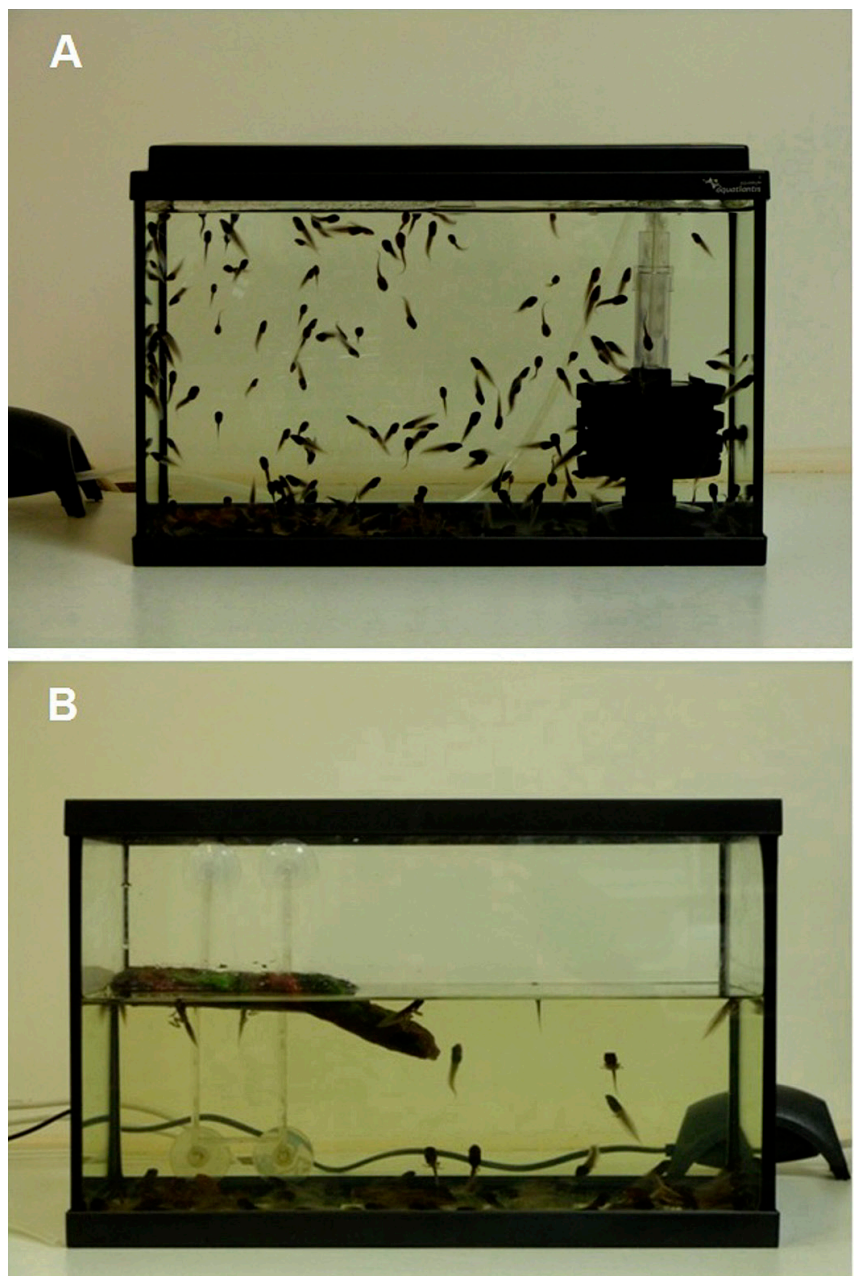

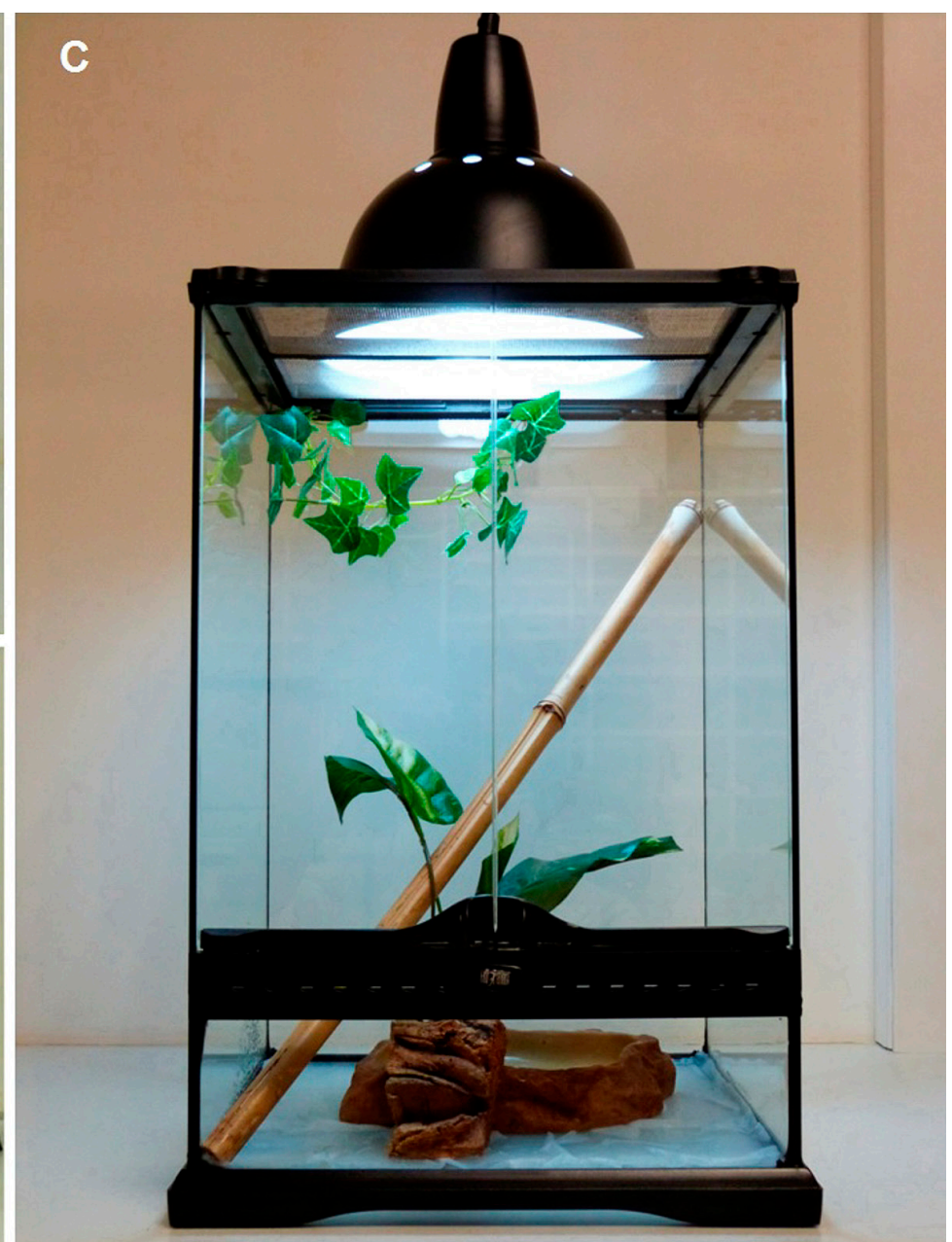

Fig. 3. Enclosure for rearing Amazonian Milk Frogs (Trachycephalus resinifictrix): (A) Tank for larvae at early developmental stages, (B) aquarium for advanced larval stages, and $(\mathrm{C})$ rearing terraria for juvenile frogs. The decoration is minimalist for hygienic reasons. 


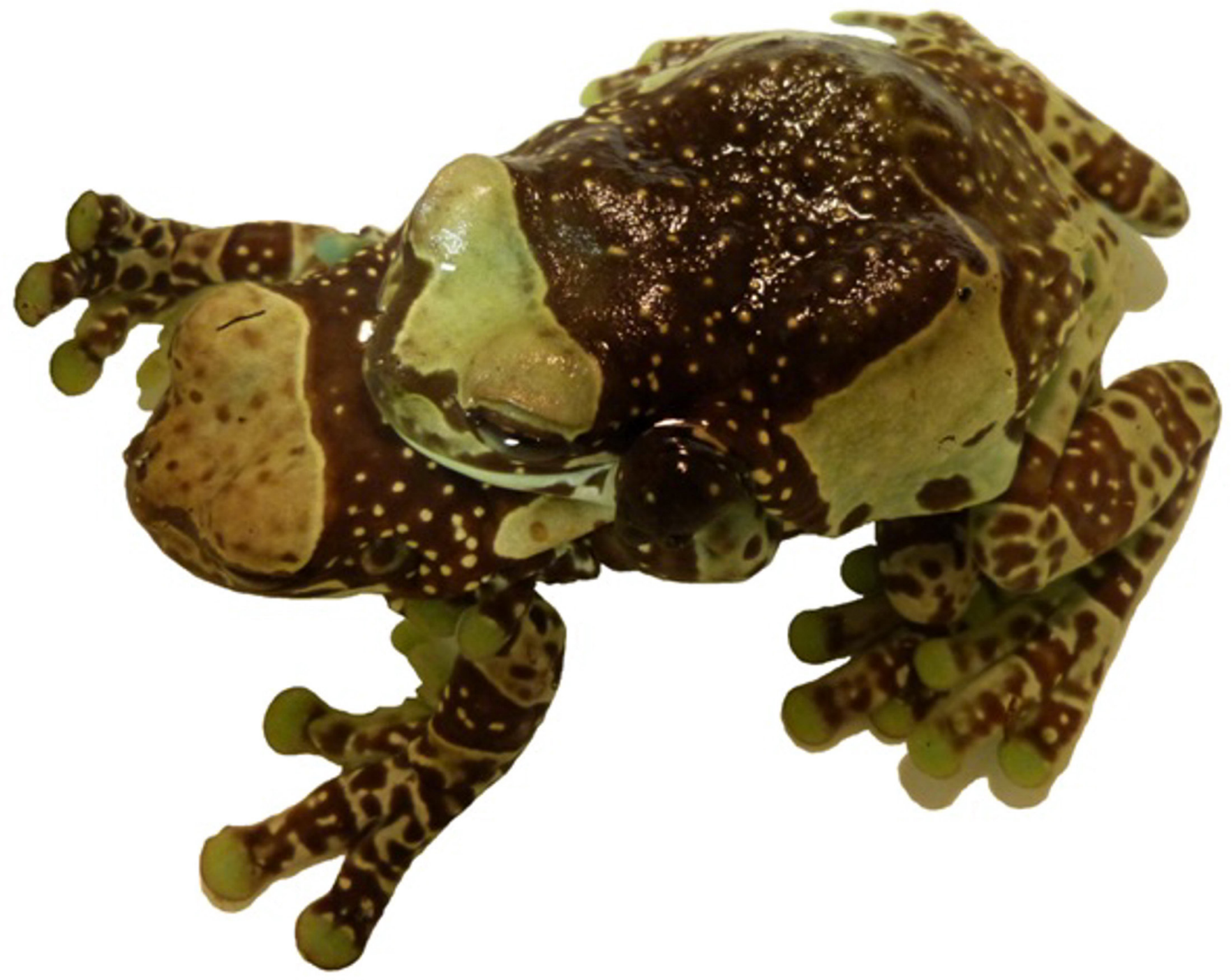

Fig. 4. Axillary amplexus of Amazonian Milk Frogs (Trachycephalus resinifictrix).

affect amphibians, some of the more commonly encountered challenges are the vitamin and mineral imbalances related to metabolic bone disease (MBD). MBD (e.g., nutritional osteofibrosis) is most frequently caused by low levels of calcium or improper calcium/ phosphorus ratios in the insects. Indeed, many insects used as food or prey, including $A$. domesticus, L. migratoria, and $D$. hydei, have low levels of calcium or imbalanced calcium/phosphorus ratios (Barker et al. 1998; Michaels et al. 2014). According to Bernard and Allen (1997), none of the species noted above is suitable as the sole component of a diet. However, this calcium deficiency can be corrected by feeding the insects calcium-rich food or by dusting the insects with a mineral supplement.

\section{Results and Discussion}

During breeding season, males can be readily distinguished from females by the presence of nuptial pads on the insides of the thumbs. Males begin to call at nightfall and eggs are deposited in water during the night. Periods of calling are interspersed with axillary amplexus (Fig. 4), but this does not necessarily lead to oviposition.

Schiesari et al. (2003) reported clutch sizes of $T$. resinifictrix in nature of 106-1,540 eggs. Here, the female deposited roughly 100-500 eggs per oviposition. The eggs are black, small (about $1.5 \mathrm{~mm}$ in diameter), and surrounded by a gelatinous capsule. In general, hatching occurs after 24-48 hours. Newly hatched larvae measure about $5 \mathrm{~mm}$ in total length and have external gills that quickly disappear. Immediately after hatching, tadpoles float at the surface of the water for several days. Some larvae measure about $3.5 \mathrm{~cm}$ (with tail) after four weeks of development (Fig. 5A). Only 40 days after hatching, a number of tadpoles already have well developed hindlegs (Fig. 5B). After only 43 days (i.e., 6 weeks) of development, some tadpoles have formed front legs and their tails have started to shrink (Fig. 5C). The time of metamorphosis has not been documented for tadpoles in the wild. Here, tadpoles metamorphosed after $45-75$ days at $23-25^{\circ} \mathrm{C}$. 
A

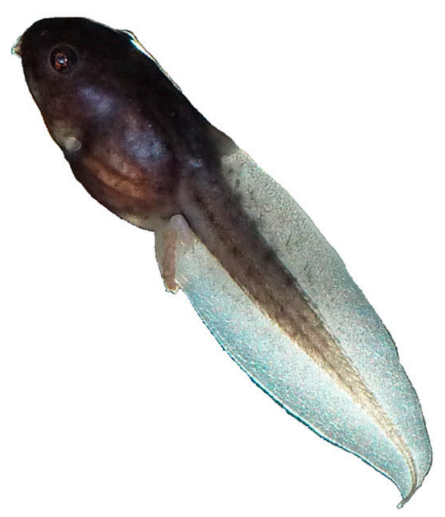

B

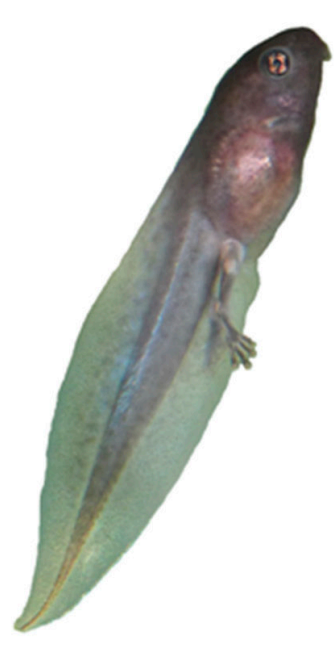

C

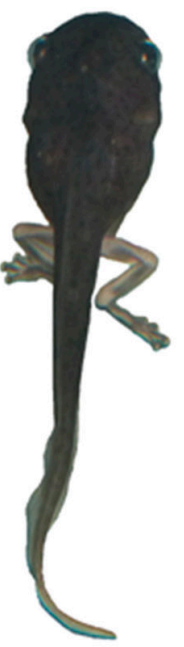

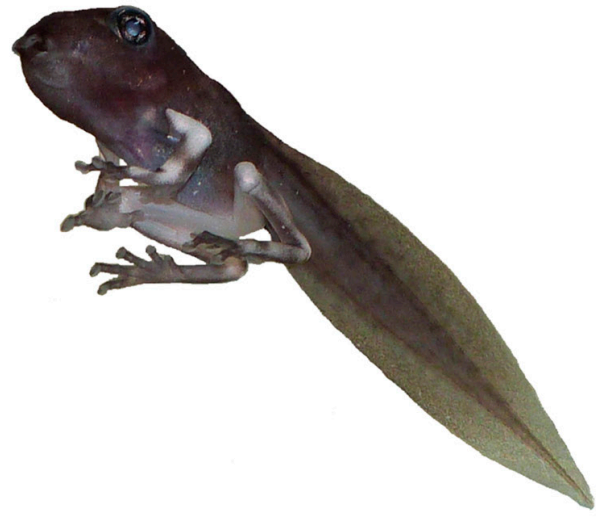

Fig. 5. Morphological changes during larval development of Amazonian Milk Frogs (Trachycephalus resinifictrix): (A) Tadpole after about 27 days of development, (B) larvae with well-developed hind legs, and (C) tadpole just prior to metamorphosis into a froglet.

Newly metamorphosed frogs measured between 1 and $1.5 \mathrm{~cm}$. The dorsum varied from dark brown to dark gray (Fig. 6A). Fore- and hindlimbs are speckled with white and the iris cross is already visible. Eighty-seven days after hatching and about one month after metamorphosis, some froglets measure between 1.5 and $2 \mathrm{~cm}$ from snout to vent. At this stage, the skin is still smooth and the color on the body of the juvenile frogs begins to change. The white coloration on the arms and legs is incorporated into the dorsal coloration. Bands of dark gray and light gray spots develop on a white background (Fig. 6B). After one year, frogs look like the adults and measure approximately $5-5.5 \mathrm{~cm}$ (Fig. 6C). The dorsal surface is primarily gray-brown in color and is covered with small pustules. The tips of the fingers are blue-green. The crossbars of the fore- and hindlimbs are dark brownish gray. Because growth beyond the initial burst immediately after metamorphosis is comparatively slow, even with abundant food, Fenolio (1998) estimated that sexual maturity is not

A

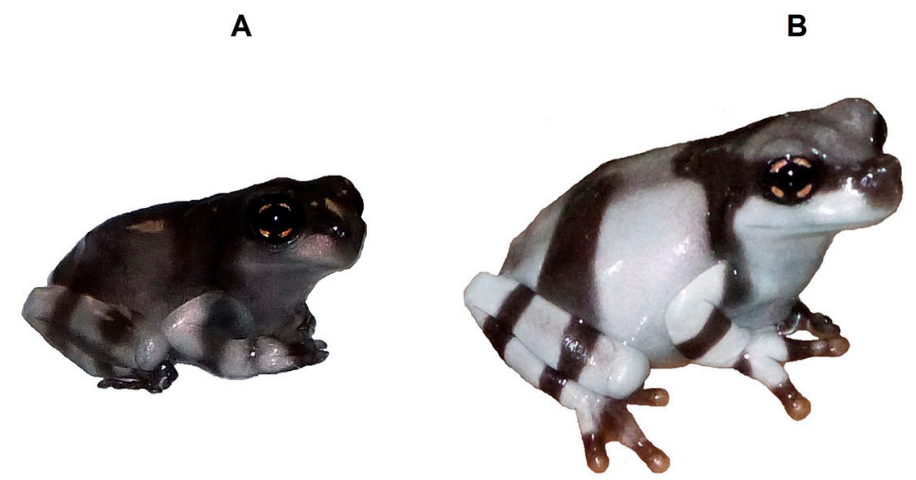

B

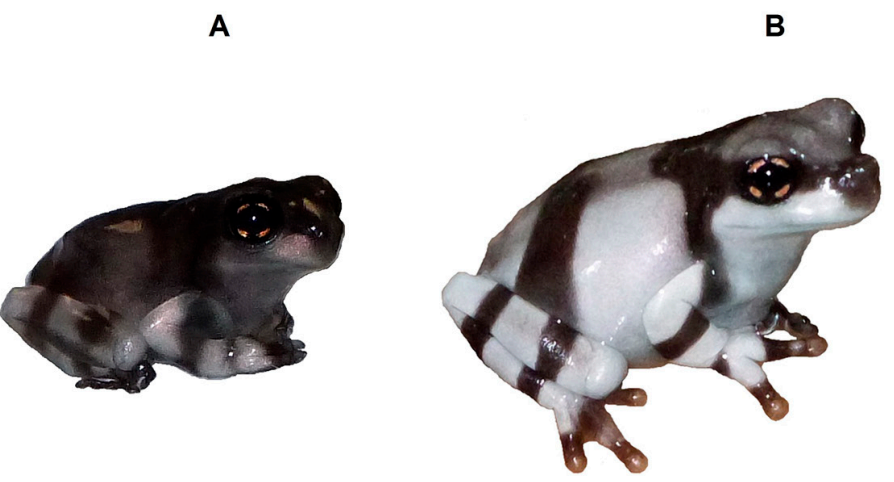

likely prior to $2 \frac{1}{2}$ years of age. However, Jungfer and Proy (1998) considered that males reach reproductive age within 10-12 months and females can deposit their first clutches after 12-15 months. In general, the larger frogs tended to reach sexual maturity after one year, whereas smaller frogs often did not reach maturity until the second year (Wells 2007). Here, individuals have not reached average adult size (ㅇ: 86-90 mm, up to $100 \mathrm{~mm}$; ${ }^{\lambda}$ : 65-77 mm) after one year of development. Especially females are unlikely to reach sexual maturity at one year of age. However, I currently have no way of verifying this, and no studies mention the minimum size at sexual maturity for either males or females in captivity or in the wild (e.g., in males, the SVL of the smallest specimen with nuptial pads from a representative sample of the population could be used to estimate the minimum size at sexual maturity).

While keeping and breeding $T$. resinifictrix at Touroparc Zoo, I noted that these frogs could breed year round. Other

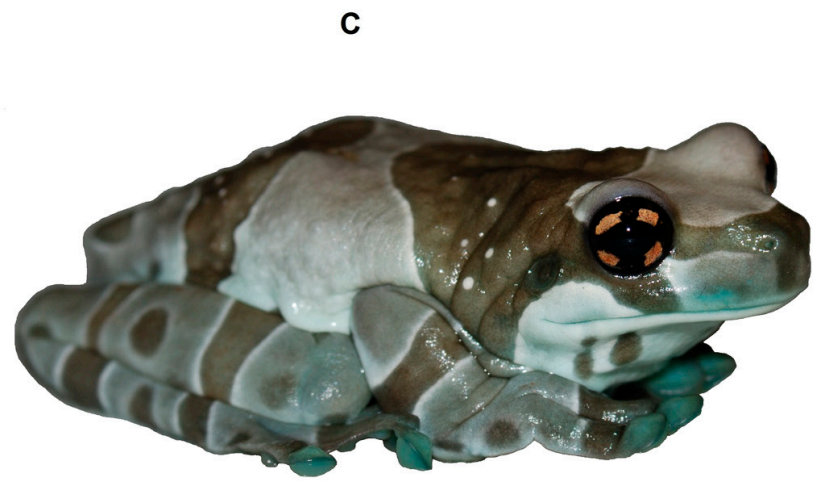

Fig. 6. Morphological changes and development of the color pattern in Amazonian Milk Frogs (Trachycephalus resinifictrix): (A) Immediately after metamorphosis, (B) at one month of age, and (C) at one year of age. 
institutions have reached similar conclusions. However, in order to contribute to the wellbeing of the animals, and also to obtain high-quality clutches, I believe that providing frogs with an annual rest period is advisable.

I observed a very low mortality rate throughout larval development. However, I observed a wide variation in developmental time. While most tadpoles finished metamorphosis about 10 weeks after egg deposition, others did not metamorphose for 14-16 weeks or even longer. Variation in growth among individuals from the same spawn reared in similar conditions can result from genetic influences, competition (Pryor 2014), or complex interactions with environments (e.g., colonization of the digestive tract by unicellular algae of the genus Prototheca; Richards 1958, 1962). The range of this variation in natural conditions is unknown. Nonetheless, further research is necessary in order to gain a better understanding of the processes affecting growth rates of $T$. resinifictrix in captivity.

About 2-3 weeks after metamorphosis, I observed an abnormal mortality. Some individuals showed abdominal bloating (edema) and death usually occurred within 24-48 hours after the first clinical signs. The edema may be caused by a wide variety of pathogens (or toxins), such as nitrites, parasites (e.g., flagellates, nematodes), bacteria (e.g., mycobacteria, chlamydiales), fungi (chytrids), or viruses (Frank Pasmans, pers. comm.). In addition, diversions from ideal environmental conditions may be extremely detrimental to health and may contribute either directly to development of disease or act as one or more stressors that indirectly predispose amphibians to diseases (Densmore and Green 2007). Many factors constitute stressors in captive environments. In amphibians, several studies have shown that handling may be stressful, as for example in the Whistling Frog, Litoria ewingii (Coddington and Cree 1995). Also, according to Carlstead and Shepherdson (2000), the presence of the public can be a stressor from which a confined animal has no escape. In light of the above, I isolated the enclosures in a room without public access and restricted access only to the animal keeper. The frequency of handling and changes of terraria as part of cleaning operations were reduced to an absolute minimum. Consequently, the mortality rate stabilized and then decreased substantially after only a few weeks. Although interesting, I did not conduct autopsies of froglets to identify the pathogen (or toxin) responsible for the spike in mortality after metamorphosis. Regardless, I strongly recommend that stress factors (e.g., repeated handling, poorly adapted housing conditions, changes of terraria, excess food) be reduced in order to avoid weakening the immune systems of froglets.

\section{Conclusions}

This species is not particularly demanding and can be bred very easily in captivity under conditions that comply with various hygiene and animal welfare standards. Before attempting to breed $T$. resinifictrix or any species with similar biologi- cal requirements, one must consider that hundreds of frogs can result from a single successful breeding. Also important is the need to test any new animal acquired for the presence of Batrachochytrium dendrobatidis and ranaviruses. This will prevent any risk of spread within an animal collection but also in nature during potential reintroduction operations. I hope my successful keeping, breeding, and raising of $T$. resinifictrix provides a reproducible model that can be used for contributions to conservation breeding programs for endangered species that have the same specific requirements as this fascinating tree frog.

\section{Acknowledgments}

I extend warm thanks to Norin Chai (National Museum of Natural History, Menagerie of the Jardin des Plantes, Paris, France) for his wise advice and interesting exchanges; Frank Pasmans (Laboratory for Veterinary Bacteriology and Mycology, Ghent University, Belgium) and Claude Miaud (Laboratory for Biogeography and Ecology of Vertebrates, Centre for Functional and Evolutionary Ecology CNRS UMR 5175, Montpellier, France) for their useful comments and additions that improved the manuscript; Pierre Joly (Laboratory of Ecology of Natural and Human-impacted Hydrosystems CNRS UMR 5023, Villeurbanne, France) for his help in interpreting some phenomena; and Marilou Prieux for her invaluable assistance in caring for froglets.

\section{Literature Cited}

Ankley, G.T., S.A Diamond, J.E.Tietge, G.W. Holcombe, K.M. Jensen, D.L. DeFoe, and R. Peterson. 2002. Assessment of the risk of solar ultraviolet radiation to amphibians. I. Dose-dependent induction of hindlimb malformations in the Northern Leopard Frog (Rana pipiens). Environmental Science and Technology 36:2853-2858.

Barker, D., M.P. Fitzpatrick, and E.S. Dierenfeld. 1998. Nutrient composition of selected whole invertebrates. Zoo Biology 17:123-134.

Bernard, J.B. and M.E. Allen. 1997. Feeding captive insectivorous animals: Nutritional aspects of insects as food. Nutrition Advisory Group Handbook, Fact Sheet 003. American Zoo and Aquarium Association, Silver Spring, Maryland.

Blaustein, A.R., D.P. Chivers, L.B. Kats, and J.M. Kiesecker. 2000. Effects of ultraviolet radiation on locomotion and orientation in Roughskin Newts (Taricha granulosa). Ethology 106:227-234.

Blaustein, A.R., J.M. Romansic, J.M. Kiesecker, and A.C. Hatch. 2003. Ultraviolet radiation, toxic chemicals and amphibian population declines. Diversity and Distributions 9:123-140.

Blaustein, A.R., J.M. Romansic, and E.A. Scheessele. 2005. Ambient levels of ultraviolet-B radiation cause mortality in juvenile Western Toads, Bufo boreas. American Midland Naturalist 154:375-382.

Browne, R.K., K. Wolfram, G. García, M.F. Bugaturov, and Z.J.J.M. Pereboom. 2011. Zoo-based amphibian research and conservation breeding programs. Amphibian and Reptile Conservation 5(3):1-14.

Carlstead, K.J. and D. Shepherdson. 2000. Alleviating stress in zoo animals with environmental enrichment, pp. 337-354. In: G.P. Moberg and J.A. Mench (eds.), The Biology of Animal Stress. Basic Principles and Implications for Animal Welfare. CABI Publishing, Wallingford, Oxon, UK.

Coddington, E.J. and A. Cree. 1995. Effect of acute captivity stress on plasma concentrations of corticosterone and sex steroids in female Whistling Frogs, Litoria ewingii. General and Comparative Endocrinology 100:33-38.

Croteau, M.C., M.A. Davidson, D.R.S. Lean, and V.L. Trudeau. 2008. Global increases in Ultraviolet B radiation: Potential impacts on amphibian development and metamorphosis. Physiological and Biochemical Zoology 81:743-761. 
Croteau, E. and C.L. Mott. 2013. Saving endangered species: A case study using global amphibian declines. Nature Education Knowledge 4(4):9.

Culley, D.D. 1992. Managing a Bullfrog research colony, pp. 30-40. In: D.O. Schaeffer, K.M. Kleinow, and L. Krulisch (eds.), The Care and Use of Amphibians, Reptiles and Fish in Research. Scientists Center for Animal Welfare, Bethesda, Maryland.

Da Luz Soares, M., S. Iop, and T.G. dos Santos. 2012. Expansion of the geographical distribution of Trachycephalus typhonius (Linnaeus, 1758) (Anura: Hylidae): First record for the state of Rio Grande do Sul, Brazil. Check List 8:817-818.

Daszak, P., L. Berger, A.A. Cunningham, A.D. Hyatt, D.E. Green, and R. Speare. 1999. Emerging infectious diseases and amphibian population declines. Emerging Infectious Diseases 5:735-748.

Densmore, C.L. and D.E. Green. 2007. Diseases of amphibians. ILAR Journal 48:235-254

Faivovich, J., C.F.B. Haddad, P.C.A. Garcia, D.R. Frost, J.A. Campbell, and W.C. Wheeler. 2005. Systematic review of the frog family Hylidae, with special reference to Hylinae: Phylogenetic analysis and taxonomic revision. Bulletin of the American Museum of Natural History 294:1-240.

Fenolio, D. 1998. Notes on the captive reproduction of the Amazonian Milk Frog (Phrynohyas resinifictrix). Reptiles 1998:84-89.

Fite, K.V., A. Blaustein, L. Bengston, and H.E. Hewitt. 1998. Evidence of retinal light damage in Rana cascadae: A declining amphibian species. Copeia 1998:906-914.

Goeldi, E. 1907. Description of Hyla resinifictrix Goeldi, a new Amazonian tree frog peculiar for its breeding habits. Proceedings of the Zoological Society of London 1907:135-140.

Griffiths, R.A. and L. Pavajeau. 2008. Captive breeding, reintroduction and the conservation of amphibians. Conservation Biology 22:852-861.

Häkkinen, J., S. Pasanen, and J.V. Kukkonen. 2001. The effects of solar UV-B radiation on embryonic mortality and development in three boreal anurans (Rana temporaria, Rana arvalis and Bufo bufo). Chemosphere 44:441-446.

Hays, J.B., A.R. Blaustein, J.M. Kiesecker, P.D. Hoffman, L. Pandelova, D. Coyle, and T. Richardson. 1996. Developmental responses of amphibians to solar and artificial UVB sources: A comparative study. Photochemistry and Photobiology 64:449-456.

Jungfer, K.H. and C. Proy. 1998. Phrynohyas resinifictrix (Goeldi, 1907) der Frosch der seine Frau bei Vollmond ruft: Geschichte und Fortpflanzungsverhalten im Terrarium. Herpetofauna 20:19-29.

Kats, L.B., J.M. Kiesecker, D.P. Chivers, and A.R. Blaustein. 2000. Effects of UV-B radiation on anti-predator behavior in three species of amphibians. Ethology 106:921-931.

La Marca, E., C. Azevedo-Ramos, R. Reynolds, L.A. Coloma, and S. Ron. 2010. Trachycephalus resinifictrix. In: IUCN 2013. IUCN Red List of Threatened Species. Version 2013.2. <www.iucnredlist>.

Langhelle, A., M.J. Lindell, and P. Nyström. 1999. Effects of ultraviolet radiation on amphibian embryonic and larval development. Journal of Herpetology 33:449-456.

Lescure, J. and C. Marty. 2000. Atlas des amphibiens de Guyane. Patrimoines Naturels, Paris 45:1-388.

Lips, K.R., F. Brem, R. Brenes, J.D. Reeve, R.A. Alford, J. Voyles, C. Carey, L. Livo, A.P. Pessier, and J.P. Collins. 2006. Emerging infectious disease and the loss of biodiversity in a Neotropical amphibian community. Proceedings of the National Academy of Sciences 103:3165-3170.

Lötters, S., J. Kielgast, J. Bielby, S. Schmidtlein, J. Bosch, M. Veith, S.F. Walker,
M.C. Fisher, and D. Rödder. 2009. The link between rapid enigmatic amphibian decline and the globally emerging chytrid fungus. EcoHealth 6:358-372.

Mandloi, S., R. Mishra, R. Varma, B. Varughese, and J. Tripathi. 2013. A study on phytochemical and antifungal activity of leaf extracts of Terminalia catappa. International Journal of Pharma and Bio Sciences 4:1385-1393.

Marris, E. 2008. Bagged and boxed: It's a frog's life. Nature 452:394-395.

Michaels, C.J., R.E. Antwis, and R.F. Preziosi. 2014. Impacts of UVB provision and dietary calcium content on serum vitamin D3, growth rates, skeletal structure and coloration in captive Oriental Fire-bellied Toads (Bombina orientalis). Journal of Animal Physiology and Animal Nutrition 99:391-403.

Nagl, A.M. and R. Hofer. 1997. Effects of ultraviolet radiation on early larval stages of the Alpine Newt, Triturus alpestris, under natural and laboratory conditions. Oecologia 110:514-519.

Neelavathi, P., P. Venkatalakshmi, and P. Brindha. 2013. Antibacterial activities of aqueous and ethanolic extracts of Terminalia catappa leaves and bark against some pathogenic bacteria. International Journal of Pharmacy and Pharmaceutical Sciences 5:114-120.

Pahkala, M., A. Laurila, and J. Merilä. 2003. Effects of ultraviolet-B radiation on behaviour and growth of three species of amphibian larvae. Chemosphere 51:197-204.

Pryor, G.S. 2014. Tadpole nutritional ecology and digestive physiology: Implications for captive rearing of larval anurans. Zoo Biology 33:502-507.

Rachowicz, L.J., R.A. Knapp, J.A.T. Morgan, M.J. Stice, V.T. Vredenburg, J.M. Parker, and C.J. Briggs. 2006. Emerging infectious disease as a proximate cause of amphibian mass mortality. Ecology 87:1671-1683.

Richards, C.M. 1958. The inhibition of growth in crowded Rana pipiens tadpoles. Physiological Zoology 31:138-151.

Richards, C.M. 1962. The control of tadpole growth by alga-like cells. Physiological Zoology 35:285-296.

Rosa, G.M., J.E. Cadle, A. Crottini, J. Dawson, D. Edmonds, M.C. Fisher, G. Garcia, F. Glaw, J. Glos, R.N. Harris, J. Köhler, F. Rabemananjara, S. Rabesihanaka, N. Rabibisoa, J.C. Randrianantoandro, A.P.Raselimanana, C.J. Raxworthy, H. Razafindraibe, D. Vallan, M. Vences, C. Weldon, P.C. Wright, and F. Andreone (eds.). 2015. A Conservation Strategy for the Amphibians of Madagascar. ASCAM2. Abstract Book. Museo Regionale di Scienze Naturali, Regione Piemonte, Torino.

Schiesari, L.C., B. Grillitsch, and C. Vogl. 1996. Comparative morphology of phytotelmonous and pond-dwelling larvae of four Neotropical treefrog species (Anura, Hylidae, Osteocephalus oophagus, Osteocephalus taurinus, Phrynohyas resinifictrix, Phrynohyas venulosa). Alytes 13:109-139.

Schiesari, L., M. Gordo, and W. Hödl. 2003. Treeholes as calling, breeding, and developmental sites for the Amazonian Canopy Frog, Phrynohyas resinifictrix (Hylidae). Copeia 2003:263-272.

Schultz, T.W. and A.D. Douglas. 2003. Housing and husbandry of Xenopus for oocyte production. Lab Animal 32:34-39.

Verschooren, E., R.K. Brown, F. Vercammen, and J. Pereboom. 2011. Ultraviolet $B$ radiation (UV-B) and the growth and skeletal development of the Amazonian Milk Frog (Trachycephalus resinifictrix) from metamorphosis. Journal of Physiology and Pathophysiology 2:34-42.

Wells, K.D. 2007. The Ecology and Behavior of Amphibians. University of Chicago Press, Chicago and London.

Zippel, K., K. Johnson, R. Gagliardo, R. Gibson, M. McFadden, R. Browne, C. Martinez, and E. Townsend. 2011. The Amphibian Ark: A global community for ex-situ conservation of amphibians. Herpetological Conservation and Biology 6:340-352. 